\title{
Nurturing Invulnerability in Disadvantaged Children
}

\author{
Pranati Satapathy ${ }^{1 *}$
}

\section{ABSTRACT}

Invulnerability is a process involving development of the capacity to confront, withstand, overcome and benefit from the psychologically critical /deleterious life situations such as deprivation/ disadvantages, stresses, frustration, conflicts and crisis. From time immemorial, human kind seems to have learned to develop a sort of ambivalence towards such critical situations/conditions or adversities and the pain and suffering associated with these. Operationally invulnerability may be defined as competence amidst disadvantages.

Keywords: Nurturing, Invulnerability, Children

The uniqueness of individuals is one of the most fundamental characteristic facts of life. Plants raised in the same garden from apparently identical seeds grow into different sizes and shapes and produce different numbers of blossoms. Puppies, even those from the same litter, become dogs clearly distinguishable from one another in appearance and behavior. Children in the same family differ from one another even in infancy, and as they grow they develop different initiatives and interests, different moods and manners different ways of reacting to success and failure, reward and punishment.

At all periods of human history man has observed and described differences between individuals, and psychologists have attempted and succeeded in identifying such differences. There is a truism that the human development whether psychological or physical is the product of reciprocal and dynamic interaction between nature and nurture. While heredity is used to describe the genetic contributions, the environment includes all the developmental aspect of the child, through which the child learns his /her ways of life .

Nurturing invulnerability is an idea in the global arena of psychological and educational reform movements. During 1960s, the psychologist and educationist became extremely conscious about a group of children, who filed to respond to schooling and /or lacked in certain abilities and competence. While studying these children, the researchers and psychologists used the term called "Disadvantaged “. Further, they defined the disadvantaged as those whose basic biophysio -psychological social affective-personal needs have not been met or inadequately met, whose rights have been denied, who suffer from a prolonged deprivation and whose environment

\footnotetext{
${ }^{1}$ Lecturer, PG Department of pPsychology, Ravenshaw University, Cuttack, Odisha, India *Corresponding Author (C) 2015 I P Satapathy; licensee IJIP. This is an Open Access Research distributed under the terms of the Creative Commons Attribution License (http://creativecommons.org/licenses/by/2.0), which permits unrestricted use, distribution, and reproduction in any Medium, provided the original work is properly cited.
} 


\section{Nurturing Invulnerability in Disadvantaged Children}

has failed to provide appropriate social support and cognitive stimulation at critical stages in life, for growth and development .

Beginning from common people to researchers it is a common belief that the disadvantaged children suffer from many limitations. But only a few researchers have argued and identified that there are talents among the disadvantaged children. A few studies on such children have been conducted successfully on a conceptual research model for studying and identifying disadvantage, competence and invulnerability. In this model the external environmental conditions are dichotomized as easy or advantaged and difficult or disadvantaged; and internal conditions are divided into strong or competent and weak or innocent. So the model proposes two dimension for study: the ecological environment and individual competence. Thus, while studying the children from both advantaged and disadvantaged categories by assessing their environmental facilities and academic competence in a cross classification model a group of children who come from deprived environmental background, low/uneducated parents, poor socioeconomic status were identified having markedly very high academic and behavioural competence. These children are invulnerable children.

\section{CONCEPTUAL RESEARCH MODEL FOR STUDYING INVULNERABILITY}

\begin{tabular}{|l|l|c|c|}
\hline \multirow{2}{*}{$\begin{array}{l}\text { EXTERNAL } \\
\text { CONDITIONS }\end{array}$} & \multicolumn{3}{|c|}{ INTERNAL CONDITIONS } \\
\cline { 2 - 4 } & $\begin{array}{c}\text { Easy } \\
\text { Advantaged }\end{array}$ & $\begin{array}{c}\text { Strong competent } \\
\text { Advantaged -competent } \\
\text { Lucky }\end{array}$ & $\begin{array}{c}\text { Advantaged incompetent } \\
\text { “ Rotten Apple “ }\end{array}$ \\
\cline { 2 - 4 } & $\begin{array}{c}\text { Difficult } \\
\text { Disadvantaged }\end{array}$ & $\begin{array}{c}\text { Disadvantaged - } \\
\text { competent } \\
\text { Invulnerable } \\
\text { "Lotus in the mud” }\end{array}$ & $\begin{array}{c}\text { Disadvantaged -incompetent } \\
\text { Vulnerable } \\
\text { "At risk” }\end{array}$ \\
\hline
\end{tabular}

The objective of this paper is to promote a debate /discussion (i) to know the parental child rearing style of the invulnerable children and (ii) to analyse the personality style, cognitive and social competence and coping mechanism of such children. A number of studies have been conducted in this field (Nanda, 2004).

Recent research findings indicate that the human organism appears to have been programmed by the course of evaluation to produce normal developmental outcomes under all but most adverse of circumstances. Any understanding of deviance in outcome must be seen in the light of this self connecting and self organizing tendencies which appear to move individuals towards normality in the face of pressure towards deviation. This intrinsic factor has been term as invincibility or invulnerability, which may be defined as the self -righting tendencies within children that produce normal or even superior development under all but most persistently adverse 


\section{Nurturing Invulnerability in Disadvantaged Children}

circumstances. There are strong empirical evidences that every creature has been endowed with not only some degree of vulnerability that put limitations in coping with particularly disruptive or adverse life changes, but also there is always a combination of internal and external resources working together that furnishes the individual with the necessary resilience to overcome life's stresses by remaining invulnerable. When confronted with extreme misfortune, after an initial period of crisis and strain , most persons show marked resilience and learn to respond reasonably and effectively to such challenges to adjust .

From the time immemorial, adversity has been regarded negatively as an integral part of the human condition to be suffered and endured but positively as a testing ground for the egoism of man. Adversity best discovers virtue.

It is possible to view different groups of children in two ways (i) from deficit but competent perspective and (ii) from an affluent differences but competence but competent perspective. The former is invulnerable children who comes from low deprived socio economic dimensions and deficiencies and obstacles seems to be competent at par with children belonging to enriched environment with regard to their competence in cognitive affective ,motivational , academic, social and personality style . These children are " LOTUS IN THE MUD " since thety constantly struggle with stressful, disadvantaged and threatening life and developmental set to expect the unexpected and are always alert to " CATCH THE BULL BY HORN , if needed .

On the contrary, there are children who come from well-to-do family, high socio economic dimensions, with stimulating environment, high educated parents , had good educational opportunity and nourishment but show poor cognitive, academic, behavioural and general competence who may be called as Advantaged - incompetent - children ,they are "ROTTEN APPLES” .

Psychologists concerns for and preoccupation with the disadvantaged children have significantly contributed to the study of the child development in particular and to the field of psychology as a whole. Invulnerability is often viewed as the psychic counterpart of immunity, incorporating resilience and invincibility, develops through repeated confrontations with psychologically stressful and critical life situation. Invulnerability is an inherent property of the individual self. Recent research in psychology and psychopathology has revealed that invulnerable children do not succumb to disadvantage, stress, risk or handicaps rather they excel. Both Invulnerability and vulnerability fall on a continuous scale though these may be conceptualized through the dichotomy of environmental stimulation and personal competence leading to "disadvantagecompetent" and "disadvantage - incompetent "groups. Invulnerability research implies a reorganization of our knowledge-base and understanding that every situation has both positive and negative contributions to life and growth.

In Indian socio - cultural setup, there are innumerable children with environmental adversities but have proved to be resilient. Resilience involves a global aspect of the whole child growth drive, equilibrium after disequilibrium. Different resources are mobilized in a given instance, 


\section{Nurturing Invulnerability in Disadvantaged Children}

depending on the particular strength of the individual child, as well as on the pattern of stress and its relation to the child's vulnerability. Resilience, like competence and adaptation as outcomes of coping, is an evaluative concept, not a unitary trait. The resilient child is oriented towards the future, living ahead with hope. The Indian cultural maxims and assumptions such as those presented by the children's mothers: "Every cloud has a silver lining ", Tomorrow will be a better day ". If at first you do not succeed, try again and you have to take bad with good "; overtime, support positive expectations / acceptance of reality. Those are indeed positive strokes.

It has been observed that Invulnerable children develop amidst disadvantages but because of their strong self esteem and feeling of self worth manifest better social motivational competence , so also cognitive and personal psychological functioning. They maintain the spirit of acting, reacting with the environmental adversities. The Invulnerable children are those who survive the adversities and excel the average, normal standard of achievement. These children seemed to have developed a mental set of readiness preparedness to face any eventuality to achieve their goal and the self - confidence seems to be both the cause and the effect of confrontative coping among the invulnerable.

Thus, the sense of protection against the calm reception of painful stimuli and self-confidence seems to be the hull mark of invulnerable children. It is a fact that the advantage incompetent children lived amidst all material affluence, but they suffered from a psychological poverty processing all capabilities which are mostly unutilized.

The sense of confidence in achieving the goal in an adverse physical environment but maintaining a psychological well being could reflect a reciprocal atmosphere of self respect leading to realization of self esteem, which seemed to be another hallmark of Invulnerable, and such children are expected to be competent.

It is worth and essential to know the psycho-behavioural dimension including personality and the which children are reared by their parents, so that something can be suggested as remedy for the children falling within the category of (i) rotten apple (ii) high risk (vulnerable ) and (iii) Invulnerability . Moreover, the disadvantages of the advantaged children as well as the advantages of the disadvantaged children need to be understood in proper perspective, and addresses with adequate care and concern.

REFERENCES:

Ashman,A and Elkins,J.( 1998) . Educating Children with special Needs. New York : Prentice Hall.

Hewardd,W.L and Orlansky,M.D(1992). Exceptional Children.NewYork: Maxwell Macmillan international

Kirk,S.A;Gallagher,J.J and Anastaslow,N.J (1997).Educating Exceptional Children .Boston Houghton Mifflin company. 